\title{
Környezetvédelmi törekvések a repülőgépiparban az Airbus és a Boeing példáján keresztül
}

\section{Environmental considerations in aircraft manufacturing industry through the example of Boeing and Airbus companies}

\author{
B. MEZEI ${ }^{1}$, N. BoROS ${ }^{2}$ \\ 1Debreceni Egyetem, balazs_mezei@yahoo.com \\ 2Debreceni Egyetem, nboros@eng.unideb.hu
}

\begin{abstract}
Absztrakt: Az elmúlt évtizedek alatt a repülógépipar soha nem látott fejlódésen ment keresztül. A felhasznált nyersanyagok közül a szálerôsítésú anyagok teret hódítottak, miközben egyre növekedett az repülógépipari hulladék hasznosításának aránya. A hajtómüvek üzemanyag hatékonysága szintén növekedett, az egy utasra vonatkozó CO2 kibocsátás pedig jelentösen lecsökkent. Mindemellett viszont az iparág környezetre gyakorolt hatása állandósulni látszik. Munkánk során a repülógépipar által okozott környezeti terheléseket vizsgáltuk az Airbus és a Boeing példáján keresztül. Célunk az volt, hogy az ipari növekedés és a környezet terhelése közti kapcsolatot meghatározzuk, különös tekintettel a potenciálisan alkalmazható fejlesztésekre nézve.
\end{abstract}

Abstract: Aircraft manufacturing industry has developed dynamically in the last decades. Reinforced polymers have become the most dominant raw materials, while the recycling rate of the generated industrial waste has also increased. The fuel efficiency of the engines has increased, and the emitted CO2 per capita has significantly fallen. However, the environmental impact of the aircraft manufacturing industry seems to reach a permanent level. In this study, we have analyzed the environmental impact and the environmental considerations of the aircraft manufacturing industry through the examples of Boeing and Airbus companies. Our goal was to determine the relation between industrial growth and the environmental impact, particularly to the potential innovations.

\section{Bevezetés}

A repülőgépipar az utóbbi évtizedekben fokozatos növekedést mutatott olyannyira, hogy a 20. század gazdasági recesszióit átvészelve, a terjeszkedés a 21. században is töretlen maradt. Az Airbus felmérései alapján a légi forgalom exponenciális jelleggel növekszik és nagyjából 15 évente duplázódik meg. Ez azt jelenti, hogy a világon jelenlévő légitársaságok várhatóan közel 30 ezer új repülőgép legyártását fogják megrendelni 2032-ig, mialatt közel 6-8 ezer kiöregedett vagy elavultnak számító 
DOI: 10.21791/IJEMS.2016.2.8.

gépet vonhatnak ki a forgalomból [1, 2, 3]. Egy ilyen előrejelzés és az azt alátámasztó adatok alapján joggal tevődik fel a kérdés: Milyen hatással lehet a repülőgépipar terjeszkedése a környezetünkre?

Munkánk során az exponenciálisan növekvő repülőgépipar által okozott környezetterhelés jellegét és mértékét vizsgáltuk. A világ két legnagyobb repülőgépipari vállalata, a Boeing és az Airbus példáján keresztül meghatároztuk, hogy a környezetvédelem hogyan nyilvánul meg a repülőgépiparban, és mi motiválja a vállalatokat a környezetvédelmi beruházásokra. Az így kapott adatok alapján értékeltük, hogy a jelenlegi tendenciák követése milyen eredményekkel és veszélyekkel járhat a jövőre nézve.

A legnagyobb repülőgépipari vállalatok által nyilvánosságra hozott adatok alapján egy a repülőgépipar egészére jellemző környezetvédelmi tendenciát határoztunk meg. Azonosítottuk a repülőgépipar azon területeit, ahol potenciálisan környezetterhelés léphet fel és felkutattuk azokat az elmúlt években közzétett környezeti jelentéseket és Európai Uniós közleményeket, melyek az iparág aktuális környezetterhelésére vonatkozó adatokat tartalmazzák. Ezek összevetésével és feldolgozásával becsültük a kialakult terhelés mértékét és súlyosságát.

Az aktuális környezeti terhelések és a vállalatokat potenciálisan motiváló tényezők mellett, a világ két legnagyobb repülőgépipari vállalatának környezetvédelmi törekvéseit is vizsgáltuk. Az Airbus és a Boeing által végzett innovációs tevékenységek alapján egy olyan tendenciát figyeltünk meg, mely minden kisebb vállalat tevékenységére jellemző, vagy jellemző kell legyen a közeljövőben ahhoz, hogy a jelenlegi növekedés fenntartható maradhasson.

Munkánk utolsó szakaszában a kapott eredmények függvényében meghatároztuk a környezetterhelés szempontjából legérzékenyebb területeket. Az itt alkalmazott vagy potenciálisan alkalmazható technológiai módosítások pozitív és negatív oldalát, valamint ezekben rejlő lehetőségeket és veszélyeket kerestük. Ezek ismeretében felvázoltuk a lehetséges forgatókönyveket a repülőgépipar és a környezet szennyezettségére vonatkozó jövőbeni kapcsolatra nézve úgy, hogy egy környezetvédelmi szempontból előnyös, de ugyanakkor a vállalatok számára is kedvező alternatívát kerestünk.

\section{Környezetvédelmi törekvések a Repülőgépiparban}

\subsection{A repülőgépipar okozta környezeti terhelés}

A repülőgépek gyártása során fellépő környezetterhelés egészen az alapanyag beszerzésre és felhasználásra vezethető vissza. A repülőgépek felépítéséhez használt alapanyagok négy nagy csoportba sorolhatóak: alumínium, acél, titán és kompozit anyagok. Az iparág fejlődésének kezdeti szakaszában az alumínium jelentette a repülőgépek fő komponensét, hiszen a gép közel 80\%-a ebből készült. A különböző fejlesztési folyamatok során viszont az alumínium egyre inkább háttérbe szorult. Az alumínium ötvözetek elsősorban a géptörzsben, a szárnyakban és a tartószerkezetekben jelennek meg viszonylag alacsony tömegük és nagy ellenálló képességüknek köszönhetően (1. ábra).

A szálerősítésű anyagok az 1990-es években kezdtek elterjedni és 20 év alatt sikerült kiszorítaniuk a repülőgépiparban használt alumínium ötvözetek jelentős hányadát. Ezen anyagok bevezetésének célja nem feltétlenül az alumíniummal való takarékoskodás volt, hanem inkább a repülőgépek tömegének csökkentésével egyidejűleg történő ellenálló képesség növelés. Az anyaghelyettesítés mégis olyan jól 
sikerült, hogy a kompozit anyagok mára 30-50\% tömegarányt jelentenek a modern repülőgépek felépítésében. A gyártók az anyaghelyettesítéssel jelentős tömegcsökkentést értek el, ami egyfelől üzemanyag megtakarításhoz (vagyis $\mathrm{CO}_{2}$ emisszió csökkenéshez) vezetett, másfelől pedig megnövelte a repülőgépek szállítási kapacitását és hatásfokát is.

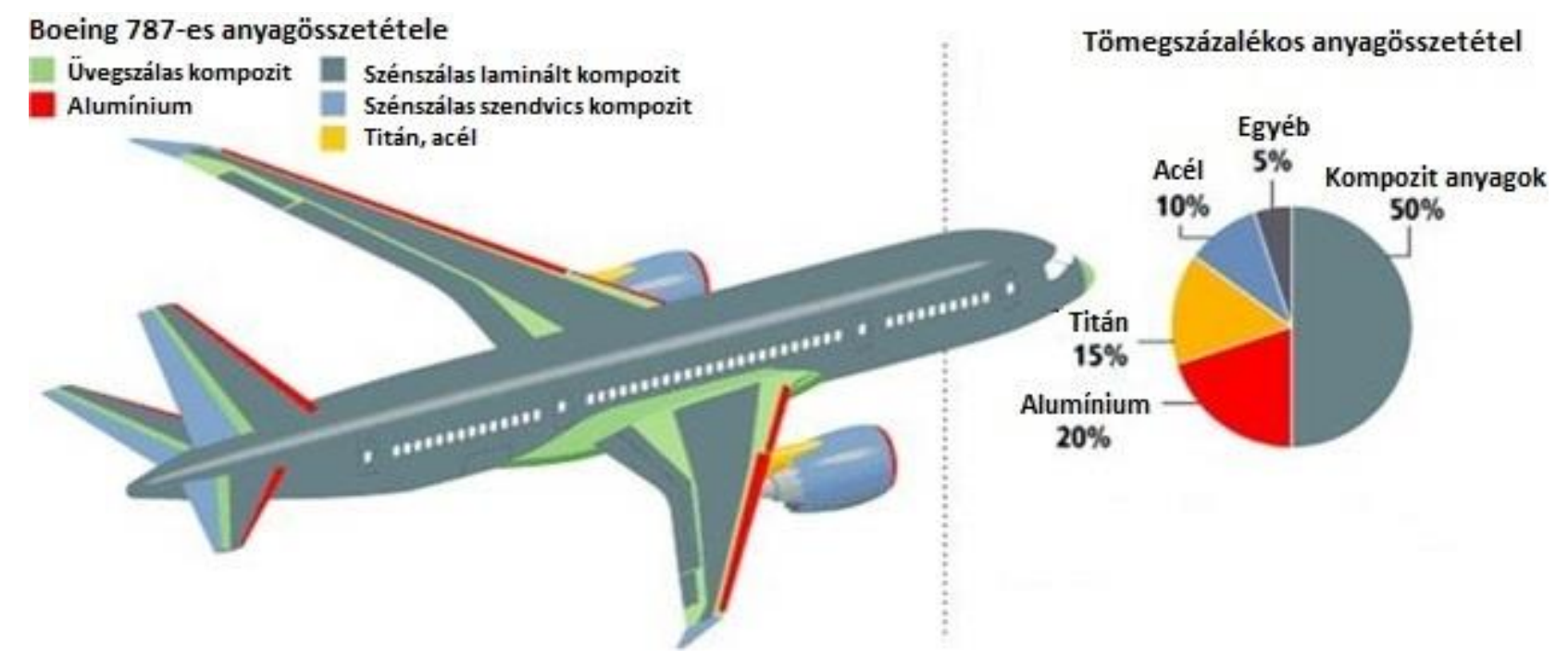

1. ábra: Az alumínium és más alapanyagok felhasználási területe a Boeing 787 gépekben [4]

Az alumínium ötvözetek szálerősítésű anyaggal való helyettesítésének ugyanakkor nem csak előnyei, hanem hátrányai is vannak. Az első és talán legnyilvánvalóbb probléma, hogy a kompozit anyagok valamilyen polimer gyanta alapon elhelyezett szén vagy üvegszálas termékek, melyek veszélyes (bőr és szemirritációs hatású) anyagok. A repülőgépipar kijelentette, hogy minden tőle telhetőt megtesz annak érdekében, hogy a gyártás során alkalmazott veszélyes anyagokat a lehető legnagyobb mértékben helyettesítse nem veszélyes anyagokkal. A szálerősítésű anyagok alkalmazásával viszont éppen az ellenkezője történik annak, amit ígértek, hiszen a nem veszélyes alumínium ötvözetek veszélyes gyanta alapú anyagokra lesznek kicserélve. Emellett észre kell venni azt is, hogy a szálerősített anyagból készült repülőgépek annyira beváltak, hogy a légitársaságoknak nem csak az új gépek vásárlása, de a régi (még forgalomban tartható) gépek lecserélése is kifizetődő. Felvetődött a magas alumínium tartalmú repülőgépek idő előtti nyugalmazása és ezáltal a forgalomból kivont járművek számának drasztikus növekedése.

A kompozit anyagok repülőgépipari alkalmazásának és a környezet védelemének kapcsolata tehát jelen esetben még nem egyértelmű. A helyzet megítélését tovább nehezíti a szálerősítésű anyagok újrahasznosítása. Ez ugyanis jelenleg még csak kísérleti stádiumban van.

A repülőgépipar második, környezeti szempontból problémás területe a gyártási hulladék kérdése. A nagyvállalatoknak az utóbbi években sikerült a környezeti célokat integrálni az ipari folyamatokba, aminek hatására az ipari hulladék képződése termelési egységre (pl. egy repülőgép) jelentősen lecsökkent. A vállalatok hangsúlyozzák, hogy a repülőgépek elóállítása során képződő hulladék mennyisége és veszélyessége is folyamatosan csökken, ám ennek ellenére az össz hulladéktermelésük nagyjából állandó maradt. Az állandósulást már célkitűzésként emlegetik, ami egyfelől érthető, hiszen a megrendelt repülőgépek száma exponenciálisan növekszik. Másfelől viszont érdemes lehet 
DOI: 10.21791/IJEMS.2016.2.8.

elgondolkodni azon, hogy a jelenlegi kibocsátás állandósulása milyen következményekkel járhat a jövőbeli generációkra nézve.

A repülőgépipar által kibocsátott $\mathrm{CO}_{2}$ szintén egy környezetvédelmi szempontból problémás területnek számít. A gyártás során légkörbe kerülő gázok mennyiségi változása az ipari hulladékhoz hasonló tendenciát mutat. A termelési egységre vonatkoztatott kibocsátás fokozatosan mérséklődik, ám a töretlenül növekvő gyártási volumen hatására az össz kibocsátott széndioxid mennyisége továbbra sem csökken. A repülőgépipari vállalatok össz kibocsátása évről-évre szinte teljesen változatlan marad, ezen állandósulás pedig már a célkitűzéseikben is megjelent. Az innovációs tevékenységek hatására ugyanakkor a hajtóművek üzemanyag hatékonysága az elmúlt 40 évben 70\%kal javult de az exponenciálisan növekvő légi forgalom hatására a légi közlekedésből származó $\mathrm{CO}_{2}$ kibocsátás dinamikusan emelkedik.

$\mathrm{Az}$ utolsó olyan problémás terület, amivel foglalkoztunk a forgalomból kivont repülőgépek hasznosítása. Ezen repülőgépek nagy része most még "repülőgép temetőkbe" kerül, ahol többnyire teljesen elértéktelenednek. A forgalomból kivont repülőgépek hasznosítása érdekében úgy a Boeing, mint az Airbus különböző kutatásokat és projekteket finanszíroz, melyek rámutattak arra, hogy a megfelelő eljárással a repülőgépek tömegükben akár 80-90\%-ban is hasznosíthatóak. Ez az arány első ránézésre rendkívül pozitív környezetvédelmi szempontból, ám ha egy kicsit tüzetesebben vizsgáljuk meg a projektek eredményeit, akkor a helyzet már korántsem olyan kedvező. A hasznosítási arány ugyanis csak abban az esetben lehet ilyen magas, ha a forgalomból kivont repülőgép sorsáról azonnal döntenek és a lehető legrövidebb időn belül hozzákezdenek a hasznosítási munkálatokhoz. Így még kinyerhetőek újrahasználható komponensek (hajtómű, futómű, elektronika egyes részei) és az anyagában történő hasznosítás is maximális hatásfokkal működhet. Késlekedés, hosszabb ideig tartó parkoltatás esetén viszont a repülőgépek értéküknek akár a 70-80 \%-át is elveszíthetik.

A repülőgépek anyagában történő hasznosítása ugyanakkor más negatívumokat is magában rejt. A hasznosítási eljárás során nyert anyagok jelentős része csak másodlagos ipari hasznosításra (pl. italos dobozok) vagy energetikai hasznosításra alkalmas. Az újrahasznosítás nem szolgáltat elsődleges, esetleg repülőgépipari hasznosításra alkalmas alapanyagokat, tehát lényegében a repülőgépek életútja messze áll a ciklikus jellegtől. Az iparág egyelőre csak elsődleges a nyersanyagokat használ fel, aminek egyfelől biztonsági, másfelől pedig gazdasági okai vannak.

\subsection{Környezetvédelem a világ két legnagyobb repülőgépipari vállalatánál}

A világ egyik legnagyobb repülőgépipari vállalata, a Boeing környezetvédelemmel kapcsolatos célkitűzései igazán az ezredforduló után kezdtek felerősödni. A Boeing által a 2012-2017 közötti időszakra kitűzött környezeti célok értelmében a vállalat elkötelezte magát a következők mellett:

- zéró növekedés az üvegházhatású gázok kibocsátásában,

- zéró növekedés a termelés során használt vízmennyiségben,

- zéró növekedés a szilárd hulladékok lerakásában,

- a veszélyes hulladék képződési rátájának növekedése nem haladja meg a vállalat terjeszkedésének mértékét [5]. 
DOI: 10.21791/IJEMS.2016.2.8.

A vállalat intenzív hulladékgazdálkodási tevékenysége (a többi nagy repülőgépipari vállalathoz hasonlóan) tulajdonképpen a 2007-es évben indult be igazán, amikor is a hulladékok lerakással történő ártalmatlanítása egyre drágább alternatívává vált. A Boeing egyre nagyobb hangsúlyt fektetett a lerakásra kerülő hulladékok minimalizálására, szétválogatására, az újrahasználatra valamint az újrahasznosításra. Ennek eredményeként 2007 és 2012 között 36\%-kal növelte meg a szétválogatott hulladék mennyiségét [6]. Az eredményeket elsősorban a minimalizálás, újrahasználat, újrahasznosítás és energetikai hasznosítás együttes alkalmazásával érte el a vállalat, mely eljárások mögött olyan a Boeing által is támogatott kutatási projektek és egyezmények állnak, mint az AFRA.

Az AFRA (Aircraft Fleet Recycling Association) egy 2006-ban 11 repülőgépipari vállalat által létrehozott, mára 34 taggal rendelkező szövetség, mely a forgalomból kivont repülőgépek maximális hatékonyságú hasznosítását célozza. Az AFRA mérései alapján jelenleg a repülőgépek anyagának 35\%a kerül lerakásra és 65\%-a hasznosításra. A hasznosítás alapvetően másodlagos (50\%), elsődleges hasznosításra csupán a visszanyert anyagok 15\%-a kerül, az energetikai és a repülőgépipari hasznosítás pedig teljesen hiányzik (2. és 3. ábra).

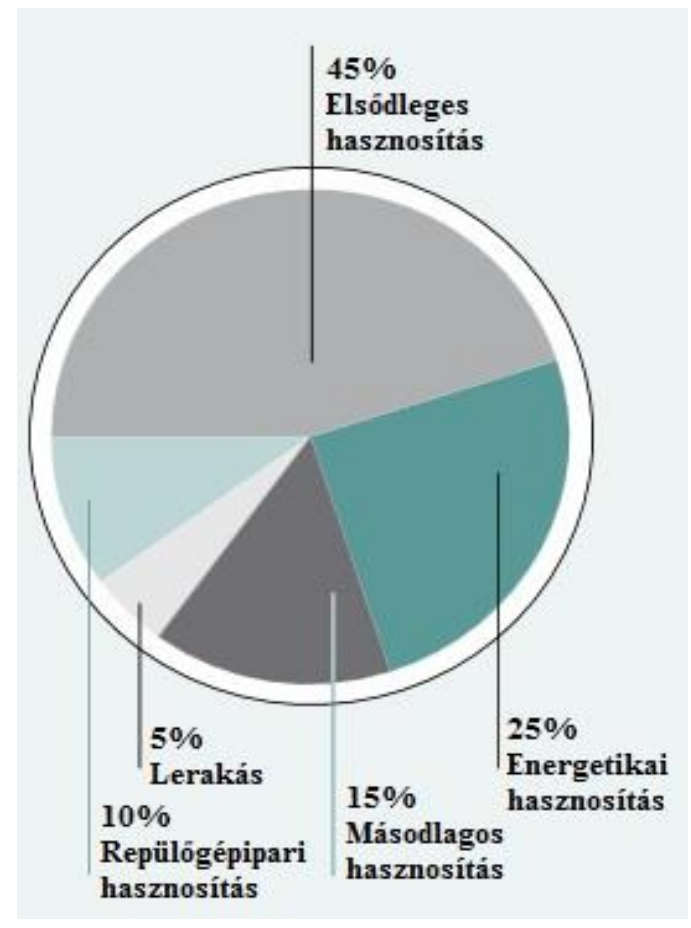

2. ábra: Az AFRA tevékenysége során nyert anyagokjelenlegi hasznosítási területei [7]

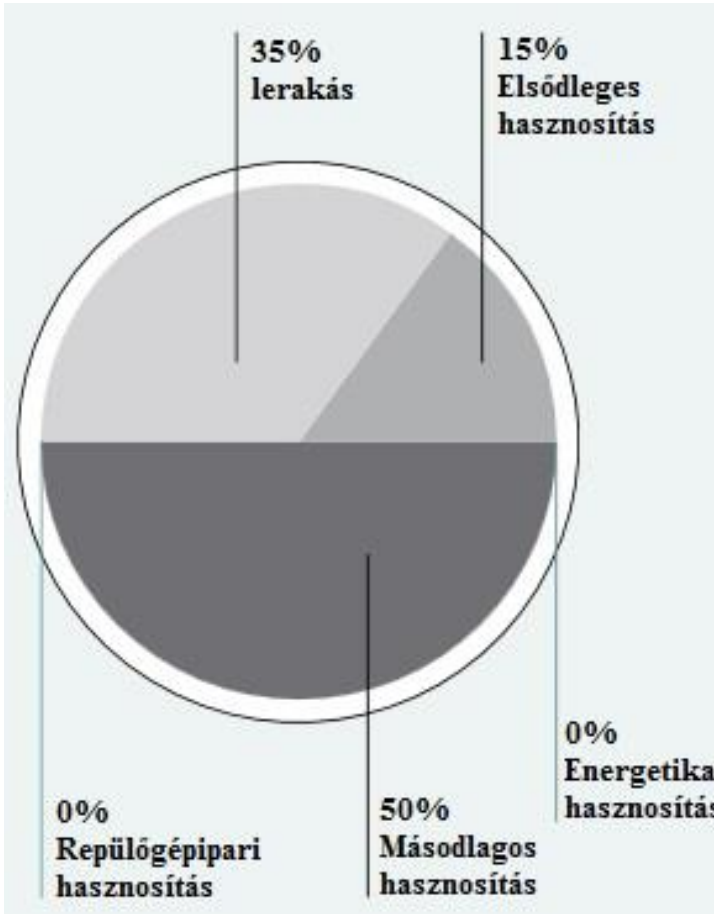

3. ábra: Az AFRA tevékenysége során nyert anyagok tervezett hasznosítási területei [7]

A 3. ábra ugyanakkor azt is mutatja, hogy az AFRA a jövőben egy 95\%-os hasznosítási arányt akar állandósítani minden repülőgép esetén úgy, hogy azoknak csupán 5\%-a kerüljön lerakásra. A szövetség célja, hogy a visszanyert anyagok legnagyobb hányada (45\%), a másodlagos hasznosítás 
DOI: 10.21791/IJEMS.2016.2.8.

(15\%) rovására elsődlegesen legyen hasznosítva, emellett pedig további 10\% kerüljön vissza a repülőgépipar termelési láncába. Az energetikai hasznosítás mértékét az AFRA 0-ról 25\%-ra növelné.

A 2000-es évek elején felerősödő környezeti szemlélet hatására az Airbus is integrálta a környezeti célkitűzéseit a termelési folyamatába. Az öko-hatékonyság elérésének eszközeként az Airbus az életciklus elemzést választotta, melynek értelmében a vállalat a repülőgépek életciklusát öt szakaszra osztja. Az életciklus elemzés első lépése a tervezés, ami talán hulladékgazdálkodási szempontból az egyik legjelentősebb fázisnak tekinthető. A cég ugyanis igyekszik a forgalomból kivont repülőgépek újrahasznosítási lehetőségeit már a tervező fázisba integrálni úgy a nyersanyaghasználat, mint a feldolgozási módok területén. Emellett az üzemeltetéssel járó szén-dioxid kibocsátás minimalizálására és a repülőgépek tömegének csökkentésére irányuló innovációk is ebben a fázisban kerülnek kidolgozásra.

A beszerzés során az ISO 14001-es szabványrendszer alkalmazása a meghatározó. A vállalat kötelezi a beszállítóit arra, hogy eleget tegyenek a szabványrendszer követelményeinek biztosítva ezáltal az alapanyagok és alkatrészek megfelelő minőségét és környezetvédelmi megfelelőségét. Az életciklus elemzés harmadik lépése a gyártás. A repülőgépek gyártása során keletkező környezetterhelés mérséklésének érdekében az Airbus egy sajátos elvet, a Blue5 elvet követ. Ennek értelmében a vállalat célul tűzte ki magának azt, hogy 2020-ig 30\%-os csökkentést ér el ki az energiafelhasználás területén, illetve 50\%-al csökkenti a termelés során felhasznált vízmennyiséget, a képződő hulladék mennyiségét, a szén-dioxid kibocsátást, valamint az illékony szerves szennyező anyagok kibocsátását.

$\mathrm{Az}$ életciklus elemzés utolsó előtti lépése a repülőgép üzemeltetés, mely tulajdonképpen magát az üzemanyag felhasználást és a $\mathrm{CO}_{2}$ kibocsátást fogja jelenteni. Ezen emissziók csökkentése érdekében a vállalat a korszerű légi forgalom menedzsment technikákat és az alternatív üzemanyagok felhasználási lehetőségeit kutatja. A forgalomból kivont repülőgépek hasznosítási lehetőségeinek kutatása érdekében az Airbus 2005-ben elindította a PAMELA Projektet.

A PAMELA (Process for the Advanced Management of End-of-Life Aircraft) egy 2005-2007 között lezajló projekt volt, melyet az Airbus finanszírozott. Célja a forgalomból kivont repülőgépek hasznosítási fokának javítása mely tartalmazza a szétszerelést, újrahasználatot, újrahasznosítást és a veszélyes hulladékok ártalmatlanítását is. A projektet az Európai Bizottság támogatta, eredményül pedig kimutatták, hogy bármely repülőgép minimum 85\%-ban hasznosítható [8]. A tapasztalatokat integrálták a teljes gyártási ciklusba, aminek hatására egy modern életciklus elemzést fejlesztettek ki a vállalatnál. A projekt egyik leglényegesebb eredménye, hogy az Airbus a “bölcsőtől a sírig" szemléletről a "bölcsőtől a bölcsőig" szemléletre váltott.

Látható, hogy a két legnagyobb repülőgépipari vállalat - a Boeing és az Airbus - igen komolyan veszi a 21. századi környezetvédelmi elvárásokat. A vállalatok az évek során különböző kutatói, innovációs és integrációs tevékenységek során a környezetvédelmet beépítették a repülőgépek teljes életciklusába. A Boeing a "Best Management Practice” (Legjobb Irányítási Gyakorlat), az Airbus pedig a „Cradle-toCradle” (Bölcsőtől a Bölcsőig) szemlélettel fogalmazza meg lényegében ugyanazt, azaz a repülőgépek újrahasznosítását biztosító feltételek termelésbe való integrálását. A két vállalat módszere tehát kicsit eltérő, de céljaik megegyeznek egymással. 


\section{Konklúzió}

A dolgozatban az exponenciálisan növekvő repülőgépipar és az általa okozott környezeti terhelés kapcsolatát vizsgáltuk meg a Boeing és az Airbus vállalatok példáján keresztül. A vizsgálat során bebizonyosodott, hogy a két vállalat által kitűzött környezeti célok rendkívül hasonlóak, meglepő módon viszont nem a teljes kibocsátás mérséklésére, hanem a jelenlegi kibocsátások állandósítására irányulnak. A környezeti fejlesztések folyamatosan zajlanak, de az iparág képviselői úgy vélik, hogy az emisszió csökkentés mértéke még a legkedvezőbb esetben is csak elérheti a repülőgépipar növekedésének mértékét. Céljuk tehát nem a kialakult környezeti terhelés mérséklése, hanem annak állandósítása töretlen ipari növekedés mellett.

Munkánk során négy olyan terület azonosítottunk, ahol a környezeti terhelés csökkentésére irányuló tevékenységek vagy ezek hiánya potenciális veszélyforrást jelenthet a jövő generációira nézve. Ezek:

- a szálerősítésű anyagok alkalmazása,

- $\quad$ az össz hulladék képződés csökkentésére irányuló törekvések hiánya,

- az össz $\mathrm{CO}_{2}$ kibocsátás csökkentésére irányuló intézkedések hiánya,

- valamint a leselejtezett repülőgépek bontásából származó anyagok elsődleges és repülőgépiparon belüli hasznosításának hiánya.

Az elvégzett vizsgálatok az Airbus és a Boeing vállalatok által közzétett, valamint az Európai Unió jelentéseire épülnek, viszont valószínűsíthetően ezek az eredmények az iparág egészére általánosan érvényesek lehetnek. A repülőgépipar tevékenysége jelentős környezetterheléssel jár és az ipari növekedés exponenciális jellege a helyzet fokozódását eredményezheti úgy, hogy még maguk a vállalatok szerint is a környezetterhelés zéró növekedése mellett történő terjeszkedés a lehető legkedvezőbb opció.

\section{Hivatkozások}

[1] Frida Andersson, Astrid Hagqvist, Erik Sundin and Mats Björkman (2014): Design for Manufacturing of Composite Structures for Commercial Aircraft - the Development of a DFM strategy at SAAB Aerostructures. Procedia CIRP 17, 362-367.

[2] Vicki P. McConnell (2010): Launching the carbon fibre recycling industry. Reinforced Plastics 54, 33-37.

[3] Kristina Wiren (2014): Airbus - Point of inflexion or point of departure? Investment Panel Copenhagen.

[4] http://modernairliners.com/boeing-787-dreamliner/boeing-787-dreamliner-specs

[5] The Boeing Company (2014): Summary Environment Report. Chicago, Illinois 60606.

[6] The Boeing Company (2013): Environment Report. Chicago, Illinois 60606. 
International Journal of Engineering and Management Sciences (IJEMS) Vol. 1. (2016). No.2.

DOI: 10.21791/IJEMS.2016.2.8.

[7] William Carberry (2008): Airplane Recycling Efforts, Benefit Boeing Operators. Aeromagazine Q4.

[8] Bruno Costes (2007): PAMELA - Process for Advanced Management of End of Life Aircraft, Layman report. 